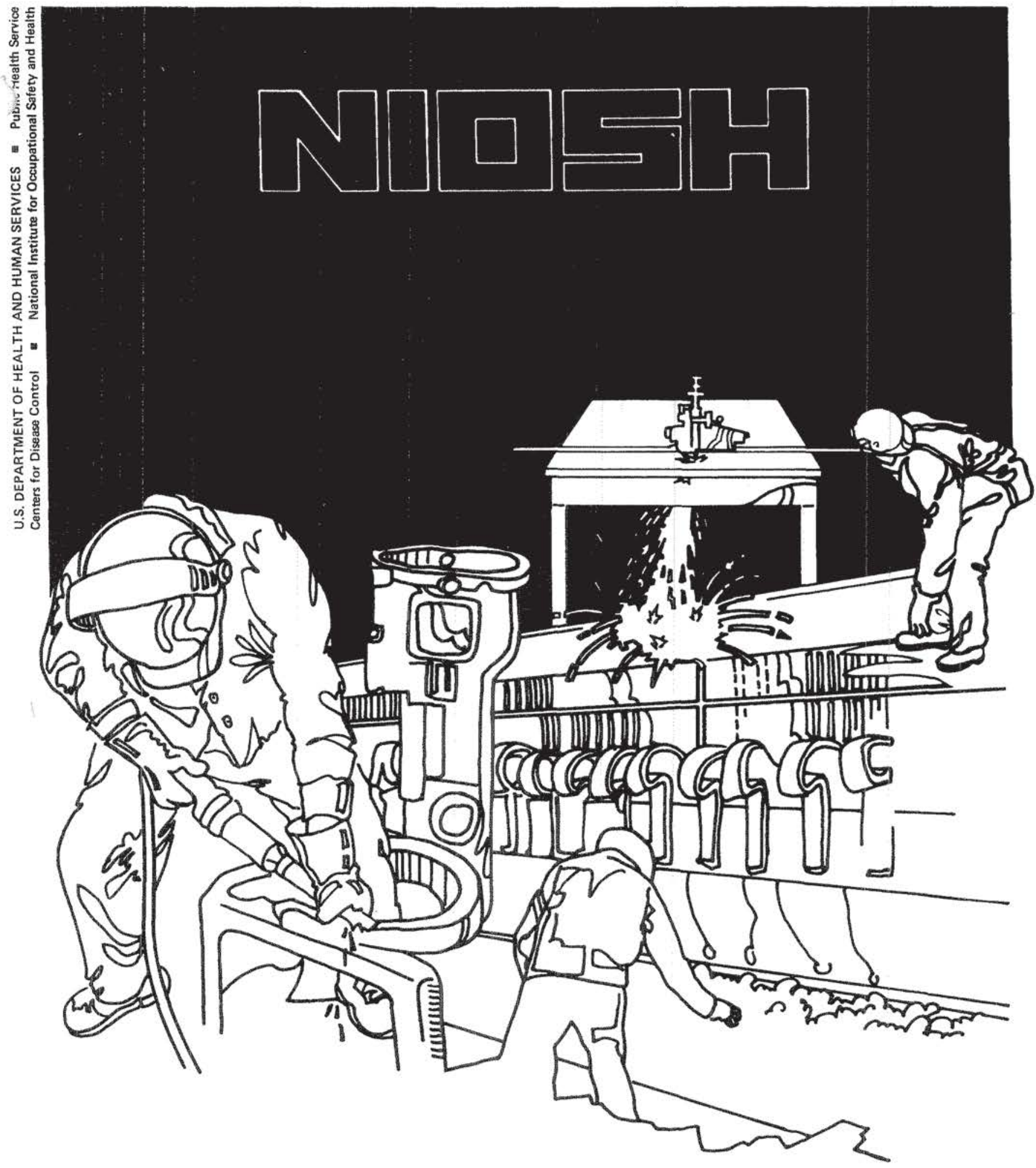

Health Hazard Evaluation Report

HETA 81-114-977 APOLLO MANUFACTURING COMPANY GRAND RAPIDS, MICHIGAN 


\section{PREFACE}

The Hazard Evaluations and Technical Assistance Branch of NIOSH conducts field investigations of possible health hazards in the workplace. These

investigations are conducted under the authority of Section $20(a)(6)$ of the Occupational Safety and Health Act of 1970, 29 U.S.C. 669(a)(6) which authorizes the Secretary of Health and Human Services, following a written request from any employer or authorized representative of employees, to determine whether any substance normally found in the place of employment has potentially toxic effects in such concentrations as used or found.

The Hazard Evaluations and Technical Assistance Branch also provides, upon request, medical, nursing, and industrial hygiene technical and consultative assistance (TA) to Federal, state, and local agencies; labor; industry and other groups or individuals to control occupational health hazards and to prevent related trauma and disease.

Mention of company names or products does not constitute endorsement by the National Institute for Occupational Safety and Health. 
HETA $81-114-977$

October 1981

Apo110 Manufacturing Company

Grand Rapids, Michigan
NIOSH Investigator:

David L. Conover, Ph.D.

I. SUMMARY

On December 1, 1980, a request for assistance was submitted to the Nationa? Institute for Occupational Safety and Health by the Michigan Department of Public Health to evaluate radiofrequency (RF) radiation exposures from dielectric heaters at Apollo Manufacturing Company, Grand Rapids, Michigan.

NIOSH conducted an evaluation of 12 RF sealers on December 8, 1980. Mean squared electric field strength measurements showed that exposures were in the range of $4.5 \times 10^{3}$ to $4.1 \times 10^{5} \mathrm{~V}^{2} / \mathrm{m}^{2}$; exposures from 4 sealers exceeded the electric field equiva?ent $\left(4 \times 10^{4} \mathrm{~V}^{2} / \mathrm{m}^{2}\right)$ of the current OSHA RF standard. Mean squared magnetic field strength measurements showed that exposures were in the range of 0.07 to $0.51 \mathrm{~A}^{2} / \mathrm{m}^{2}$; exposures from two sealers exceeded the magnetic field equivalent $\left(0.25 \mathrm{~A}^{2} / \mathrm{m}^{2}\right)$ of the OSHA standard; one of these two sealers had also exceeded the standard for electric field strength. Installation of appropriate shielding should reduce RF emissions from all sealers well helow the OSHA standard.

On the basis of the data collected in this investiaation, NIOSH determined that a radiation hazard exists, since 5 of the 12 RF sealers surveyed exceeded the OSHA RF/Microwave occupational exposure standard. NIOSH recommends that occupational exposure from all 24 RF sealers be evaluated and any exposures be reduced to less than the OSHA standard, by appropriate shielding.

KEYWORDS: SIC 3079, heat sealers, RF/microwave radiation 
HETA 81-114, Paqe 2

\section{INTRODUCTION}

On December 1, 1980, a request was received by NIOSH to evaluate the radiofrequency (RF) radiation from dielectric heaters at Apollo Manufacturing Company, Grand Rapids, Michigan. No specific health and safety complaints were reported. The Division of 0ccupational Health, Department of Public Health, Lansing, Michigan, made the request for assistance. On December 8, 1980, a representative number of the RF sealers were surveyed for RF radiation.

II I. BACKGROUND

Apollo Manufacturing Company produces vinyl products such as briefcases and pouches using dielectric heaters for sealing. Approximately 24 workers operate the sealers used in these processes.

IV. METHODS

RF electric field measurements were taken with a Holaday Model HI-300I $(S / N 26004)$ and two Holaday probes, the green probe ( $S / N$ 014) and the red probe $(S / N$ 015). The probes were calibrated on September 14, 1980 and were used to measure the mean squared electric field strength in volts squared per meter $\left(\mathrm{V}^{2} / \mathrm{m}^{2}\right)$. The minimum detectable field strength for the green probe was $5 \mathrm{~V} 2 / \mathrm{m}^{2}$ and for the red probe it was $5 \times 10^{3} \mathrm{~V} 2 / \mathrm{m}^{2}$. The maximum detectable field strength for the green probe was $10^{4} \mathrm{~V} 2 / \mathrm{m}^{2}$ and for the red probe it was $10^{7}$ $\mathrm{v}^{2} / \mathrm{m}^{2}$. The overall accuracy of both probes was $+2.0 \mathrm{~dB}(+59 \%$ to $-37 \%$ ). Both the green and red probes are used in the frequency range of $0.5 \mathrm{MHz}$ to $1,000 \mathrm{MHz}$.

The magnetic field measurements were taken with a Narda Model 25540 (S/N 04022) meter and a Narda Model 8635 (S/N 1) probe. The probe was calibrated September 4, 1980. It was used to measure the mean squared magnetic field strength in amperes squared per meter squared $\left(A^{2} / m^{2}\right)$. The minimum detectable limit for the magnetic field was $0.1 \mathrm{~A}^{2} / \mathrm{m}^{2}$. The overall accuracy for the Model 8635 probe was +3.0 $\mathrm{dB}(+100$ to $-50 \%)$. The Model 8635 probe is used in the frequency range of 10 to $300 \mathrm{MHz}$.

A Hewlett-Packard Model 5303B/5300B (SN 1520A02450/1452A02228) Frequency Counter/Measuring System Mainframe and a Singer Model 90799-2 antenna loop with an upper limit of $525 \mathrm{MHz}$ were available to identify the frequency of any detectable RF radiation found emanating from a sealer.

A11 mean squared electric and magnetic field strength measurements were corrected for frequency dependence and, since RF sealers emit intermittent radiation, for the operational duty cycle. The operational duty cycle for RF sealers is defined as the ratio of the time the radiation was on to the sum of the time the radiation was on and off during a 6-minute period. 
HETA 81-114, Page 3

V. EVALUATION CRITERIA

The OSHA RF/Microwave occupational exposure standard (29CFR 1910.97) is a power density of $10 \mathrm{~mW} / \mathrm{cm}^{2}$, averaged over any possible 6-minute period. The mean squared electric and magnetic field strength limits averaged over a 6 minute time period that are equivalent in the far field to the OSHA standard are presented in Table 2.

VI. RESULTS

Of the approximately 24 RF sealers at Apollo Manufacturing Company, Grand Rapids, Michigan, measurements were made on 12 that were considered representative of the types of sealers present. Time did not allow measurements on the rest. The measurement data are summarized in Table 1. Referring to Table 1, a total of five Cosmos RF sealers exceeded the OSHA RF/Microwave occupational exposure limits.

VII. CONCLUSIONS

A substantial portion of the RF heat sealers exceeded the occupational exposure standard. It is concluded that a health hazard from RF radiation exists for the operators of five Cosmos devices surveyed at Apollo Manufacturing Company, that radiation from the remaining RF sealers should be determined, and that any exposures in excess of the OSHA standard should be reduced by appropriate shielding.

VIII. RECOMMENDATIONS

The installation of shielding on all sealers was recommended to reduce the RF emissions below the OSHA standard. It is recommended that aluminum sheet stock and phosphor bronze spring contacts be used to construct shielded enclosures. The aluminum sheet stock would be used to construct the shielded enclosure and the phosphor bronze spring contacts would be used to ensure good electrical contact between the bottom fixed plate of the RF sealer and the open bottom of the aluminum enclosure. It was recommended that great care be taken to ensure that good electrical contact be maintained between portions of the shield. This shielded enclosure would then be connected to the dielectric insulator suporting the top plate of the RF sealer.

Apollo personnel were referred to a consultant for more detailed information on types of shielding, typical construction materials, fabrication techniques, and installation procedures.

Since RF radiation exposures from a substantial proportion (5/12) of the sealers examined exceeded the standard, it is recommended that radiation exposures from the remaining sealers be determined and that any hazardous sealers be appropriately shielded to assure that exposures of al1 operators are less than the OSHA standard. Shielding all the RF sealers should be considered since the unit cost is low and draft guidelines from the American National Standards Institute suggest that the ANSI standard will be reduced. 
HETA 81-114, Page 4

IX. AUTHORSHIP AND ACKNOWLEDGEMENTS

Evaluation Conducted and Report Prepared by:

\author{
David Conover, Ph.D. \\ Research Physicist \\ Physical Agents Effects Branch \\ Division of Biomedical and \\ Behavioral Science \\ NIOSH, Cincinnati, Ohio \\ Hazard Evaluations and \\ Technical Assistance Branch \\ Division of Surveillance, \\ Hazard Evaluations and \\ Field Studies \\ NIOSH, Cincinnati, Ohio \\ Mary E. Swenk, Secretary \\ Office of the Deputy Director \\ Division of Biomedical and \\ Behavioral Science \\ NIOSH, Cincinnati, Ohio
}

Originating Office:

Report typed by:

X. DISTRIBUTION AND AVAILABILITY

Copies of this report are currently available upon request from NIOSH, Division of Standards Development and Technology Transfer, Technical Information Branch, 4676 Columbia Parkway, Cincinnati, Ohio 45226. After 90 days the report will be available through the National Technical Information Service (NTIS), Springfield, Virginia. Information regarding its availability through NTIS can be obtained from NIOSH, Publications Office, at the Cincinnati address.

Copies of this report have been sent to:

1. Apollo Manufacturing Company, Grand Rapids, Michigan

2. Division of Occupational Health, State of Michigan

3. U.S. Department of Labor/OSHA - Region V

4. NIOSH - Region V

For the purpose of informing affected employees, a copy of this report shall be posted in a prominent place accessible to the employees for a period of 30 calendar days.

\title{
IX. REFERENCES
}

Radiofrequency (RF) Sealers and Heaters: Potential Health Hazards and their Prevention, Current Intelligence Bulletin 33, DHEW (NIOSH) Publication No. 80-107, Cincinnati, Onio, 1979, 18 pp. 
HETA 81-114, Page 5

TABLE 1

SUMMARY OF MEASUREMENT AND EXPOSURE DATA TAKEN AT APOLLO, INC December 8, 1980

HETA $81-114$

\begin{tabular}{|c|c|c|c|c|c|}
\hline Manufacturer & $\begin{array}{l}\text { Model } \\
\text { Number }\end{array}$ & $\begin{array}{l}\text { Company } \\
\text { Serial \# }\end{array}$ & $\begin{array}{l}\text { Frequency } \\
\qquad \mathrm{MHz}\end{array}$ & RF $\underset{V^{2} / \mathrm{m}^{2}}{E-F j e l d *}$ & RF $\underset{A^{2} / \mathrm{m}^{2}}{\mathrm{H}-\mathrm{Fjel}}$ \\
\hline Cosmos & 5000 & $B-7$ & 14.3 & $2.5 \times 10^{5 * \star}$ & 0.12 \\
\hline Cosmos & 3000 & $B-6$ & 24.7 & $1.4 \times 10^{4}$ & $0.27 * \star$ \\
\hline Cosmos & 3000 & $B-19$ & 24.9 & $2.8 \times 10^{4}$ & 0.18 \\
\hline Sealomatic & 400SE & $B-10$ & $20.0-21.4$ & $2.2 \times 10^{4}$ & 0.13 \\
\hline Cosmos & 6000 & $B-3$ & $0.01-18.0$ & $1.1 \times 10^{5 \star \star}$ & $0.57 * *$ \\
\hline Cosmos & 3000 & $B-22$ & 23.9 & $1.5 \times 10^{4}$ & 0.07 \\
\hline Thermatron & K108 & $B-16$ & $0.21-25.0$ & $1.0 \times 10^{4}$ & 0.14 \\
\hline Thermatron & K108 & $B-15$ & $20.0-27.0$ & $4.5 \times 10^{3}$ & 0.07 \\
\hline Sealomatic & $400 S P$ & $B-12$ & $24.0-25.0$ & $6.9 \times 10^{3}$ & 0.13 \\
\hline Cosmos & 6000 & $B-5$ & 18.0 & $4.1 \times 10^{5 \star *}$ & 0.08 \\
\hline Sealomatic & $400 \mathrm{SP}$ & $B-11$ & 21.8 & $3.5 \times 10^{4}$ & 0.07 \\
\hline Cosmos & 3000 & $B-18$ & 25.9 & $3.6 \times 10^{5 \star \star}$ & 0.14 \\
\hline
\end{tabular}

* Maximum field strengths found at operator locations, corrected for duty cycle and frequency.

** Values exceed the OSHA standard equivalent.

TABLE 2

CURRENT OSHA RF/MICROWAVE OCCUPATIONAL EXPOSURE STANDARD EQUIVALENTS HETA $81-114$

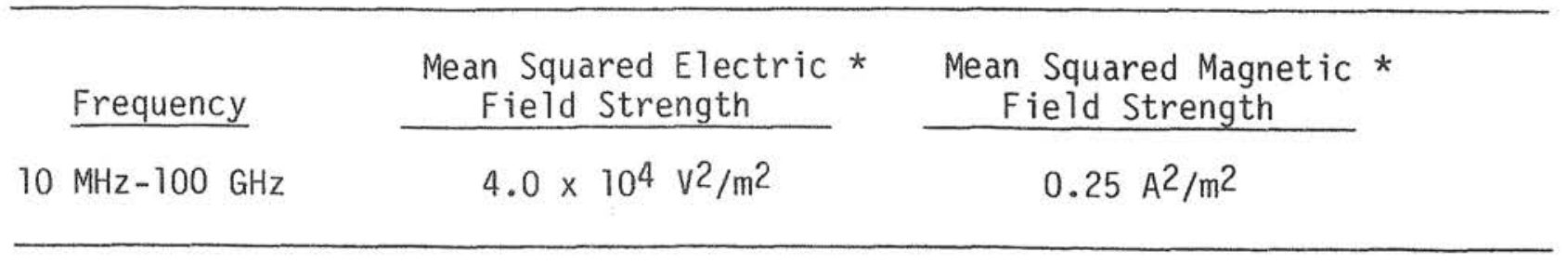

* Averaged over any possible 6-minute time period. 
DEPARTMENT OF HEALTH AND HUMAN SERVICES

PUBLIC HEALTH SERVICE

CENTERS FOR DISEASE CONTROL

NATIONAL INSTITUTE FOR OCCUPATIONAL SAFETY AND HEALTH ROBERT A. TAFT LABORATORIES

4676 COLUMBIA PARKWAY, CINCINNATI, OHIO 45226

OFFICIAL BUSINESS

PENALTY FOR PRIVATE USE, $\$ 300$
Third Class Mail

POSTAGE AND FEES D D U.S. DEPARTMENT OF HHS HHS 396 